\title{
JORGE LUIS BORGES: HISTÓRIA SOCIAL DE UM ESCRITOR NATO*
}

\author{
SERGIO MICELI
}

\section{RESUMO}

Este artigo examina condicionantes e práticas sociais que viabilizaram a trajetória literária de Jorge Luis Borges, autor que teria logrado apagar as marcas de sua vida pessoal. Por meio da análise dos textos de juventude, das relações familiares e do campo literário argentino no início do século XX, o artigo deslinda novas chaves para a compreensão da obra borgeana.

PALAVAS-CHAVE: Jorge Luis Borges; literatura argentina; modernismo; sociologia da cultura.

\section{SUMMARY}

This essay seeks the social practices that made possible the literary trajectory of Jorge Luis Borges, author who would have erased the traces of his personal life. Taking as a guideline his early writings, family relations and the Argentine literary field in the first decades of the XXth century, the article suggests new keys to the interpretation of Borges' work.

KEYWORDS: Jorge Luis Borges; Argentine literature; modernism; sociology of culture.

* Este artigo é versão do texto publicado na revista Actes de la recherche en sciences sociales, n. 168, junho de 2007.

\section{Al hijo De UM AMigo}

Ebria de significaciones

La Realidad trabaja en abierto misterio

Ylogra a veces

Que no sólo el sueño sino la vida

Nos seasueño.

Y cuando tanto logra

Lo que debía ser, cumplido está.

Porque una vez que sueño y vida,

Esas dos iluminaciones del Ser,

Confundem sus fuentes bajo nuestras miradas

El milagro inicial de Separación

En el milagro final de Identificación se agota

La Inteligencia cesa, la Visión descansa; ciérrase el círculo. 
¿Para quévino tu hijo y trae su alma

Con milagrosa humildad y altíssima cortesía

A practicar Sueño, Viday Muerte

$Y$ unirse al peregrinaje de las significaciones

Advirtiéndonos humildemente de la significación que éles?

A hacernos más ricos con saberlo

Ya formular una más completa palabra

De la ciencia de lo que nos espera.

Porque tal como yo le vi ayer

Saludar de alma a alma a una mujer

Vine a comprender lo que saludarera,

Que es reconocer la existencia de otro con tanta energía

Como la que pone Dios para invitar una alma a existir

Yesto yo no losabía

Yen retribución de enseñanza tan valiosa

Yo le digo: que no tema al ocaso

Porque es alli donde nacen más días

$Y$ es donde recibiremos un Saludo

Que nos hará verdaderamente Nacer.

Ypara allivoy caminando sin congoja alguna

Más seguro de mi eternidad y de la de mi hijo

Desde que vi cómo saluda el tujo.

Tu hijo cuyo significado es Yo Saludo

Yo aplaudo todo vivir.
Macedonio Fernández ${ }^{1}$

A copiosa literatura de exaltação do escritor argentino Jorge Luis Borges se aferrou em apagar as constrições sociais de sua trajetória, como se fora seu desígnio exclusivo a rendição ao culto do escritor puro, o mais acabado espécime contemporâneo do homem de letras, o qual teria se afirmado por força apenas do gênio literário, e cuja gênese poderia subsistir na penumbra de alusões, anedotas e esquisitices. Os artífices da legenda borgeana converteram suas ficções em néctar dos atos de escrita, um Borges cifrado que requer a prontidão cultivada do leitor, o supra-sumo da arte pela arte, a literatura desvencilhada das demais práticas sociais, e buscaram constituir um repertório de condutas, sentenças, excentricidades, caracteres, todos eles contribuindo na modelagem de um Borges tão singular e inefável.

Esse descolamento entre vida e obra lhe garantiu as roupagens sulfurosas de personas insólitas, a ponto de ser renomeado em francês como "Borgès" , esse argentino 'globalizado', destituído de vida pessoal, familiar, amorosa, infenso a paixões e tomadas de posição políti-
[1] Ver Jorge Luis Borges. Textos recobrados, 1919-1929. Buenos Aires: Emecé Editores, 1997, pp.132-133.

[2] Emir Rodríguez Monegal. Borgès.Trad. de Françoise-Marie Rosset. Paris: Seuil, 1970. Coleção Écrivains de Toujours. 
[3] Fervor de Buenos Aires (Buenos Aires:Imprenta Serantes, jul.1923, 64 pp.,300 exs. edição do autor; reedição facsimilar, Buenos Aires, Alberto Casares, 1993); Inquisiciones (Buenos Aires: Editorial Proa, abr. 1925); Luna de Enfrente (Buenos Aires : Editorial Proa, nov. 1925); El tamaño de mi esperanza (Buenos Aires : Editorial Proa, jul. 1926); El idioma de los argentinos (Buenos Aires, 1928); Cuaderno San Martín (Buenos Aires: Editorial Proa, 1929, Coleção Cuadernos del Plata, II, 280 exs.); Evaristo Carriego (Buenos Aires, 1930).

[4] Pedro Bonifacio Palacios Almafuerte (1854-1917), nascido num povoado da província de Buenos Aires, autodidata, alicerçou sua notoriedade como mestre desprendido, pronto a difundir os ideais de sua missão civilizadora nos pampas longínquos. Publicou apenas um volume de poesias em vida, Lamentaciones (1906), o que não o impediu de alcançar ampla ressonância pública por conta de composições patrióticas, que denunciam a crise argentina e frisam sua solidariedade com os pobres e humildes, em versos marcados por certo tom messiânico, de fundo cristão. Exerceu influência perceptível sobre poetas argentinos de fins do século XIX e início do XX, inclusive Lugones e Carriego. Consultar Diccionario de la literatura latinoamericana, Argentina, parte I (Washignton D.C. : Unión Panamericana, 1960, pp. 8-12) e ainda Vicente Osvaldo Cutolo, Nuevo diccionario biografico argentino (1750-1930) (Buenos Aires, Editorial Elche, 1968, tomo I, A-B, pp.94-95).

[5] Enrique J. Banchs (1888-1968), nascido em Buenos Aires, publicou aos dezenove anos o primeiro livro de versos, Las barcas, editado pela revista Nosotros em 1907. Em contraponto a Almafuerte, Banchs se firmou como a voz lírica por excelência no entresséculos, autor de baladas, canções, romanças, trovas e coplas, louvado pela mestria técnica, pelo domínio dos modelos clássicos, com forte inclinação arcaizante e medievalista. La urna (1911), justamente a composição mais apreciada pelo pai de Borges, considerada a obra-prima de Banchs, é tida como o exemplo mais perfeito da lírica argentina. Consultar Diccionario de la literatura latinoamericana, Argentina, parte II, pp. 234-238. cas, até mesmo descolado do universo cultural nativo, como se tivesse se transmutado no escritor puro por excelência, sem raízes, devotado por completo ao cometimento de uma escrita sem máculas, sem vestígio das práticas sociais que a viabilizaram. Jorge Luis Borges, o único escritor latino-americano com status de sumidade literária, teria logrado cancelar as marcas históricas de sua passagem pelo mundo social, que ele mesmo formatou como narrativa solipsista, auto-suficiente, fora do tempo e do espaço.

Borges contribuiu de modo decisivo para esse esforço minudente de "espiritualização" de suas obras, apreendidas e reconhecidas como feitos encantados de um mistagogo da narrativa ficcional. O passo crucial nesse esforço de apagamento dos sinais remanescentes dessas experiências sociais consistiu na virtual interdição de leitura, e mesmo de acesso, aos sete livros de sua autoria, publicados na mocidade, entre os versos de estréia (Fervor de Buenos Aires) em 1923, e a juntada de ensaios sob o título Evaristo Carriego, em 19303. Teve a cautela de borrar todas as marcas de vínculos afetivos, pessoais e profissionais - ao eliminar dedicatórias, omitir nomes de pessoas próximas, renomear certos poemas, como se quisesse purgar o bagaço de uma multifacetada experiência social e expressiva em favor de uma escrita ora incensada como pura invenção criativa, um artifício luminoso. Um milagre do cânon literário, que nasceu pronto e rematado, um "escritor nato".

\section{PATERNIDAde CONVULSIONADA No CÍRCULO FAMILIAR dE LETRADOS POLÍGRAFOS}

Borges foi educado num ambiente familiar de letrados, os quais costumavam se reunir em casa de seus pais, em Palermo, nas noites de domingo. Além do pai Jorge Guillermo e de Macedonio Fernández, acorriam às tertúlias domésticas diversos personagens marcantes na formação de Borges, bem como na orientação de lances decisivos de sua repentina afirmação como liderança intelectual, a meio caminho entre o queixume e a contestação: seu primo, o escritor Álvaro Melián Lafinur(1889-1958), animador do clã e vizinho de bairro; o poeta Evaristo Carriego (1883-1912), conterrâneo de Jorge Guillermo, ambos originários da província de Entre Rios, que recitava poemas seus e de outros argentinos famosos, como Lugones, Almafuerte 4 e Enrique Banchs5; o polígrafo Alfredo Palácios; Marcelo del Mazo6 (18791968), primo de Macedonio Fernández; o jornalista e poeta suíçoargentino Charles de Soussens (1865-1927). A conversa começava antes do ajantarado e se estendia até a madrugada, em torno de assuntos literários e políticos. A julgar pelas referências dos participantes, valorizavam-se as tiradas brilhantes e espirituosas, as intervenções polêmicas, as réplicas cortantes, tudo isso evidenciando a fruição 
deleitada de uma tradição de oralidade por parte dessa geração de letrados de elite na capital argentina.

Essa dinastia familiar remontava ao primeiro poeta da tradição lírica argentina,Juan Crisóstomo Lafinur(1797-1824), figura destacada daépoca da Independência. Sua reputação literária decorreu das elegias compostas por ocasião da morte do general Belgrano, de cuja academia de cadetes, em Tucumán, Juan fora aluno7. Apesar de não haver logrado um reconhecimento consistente, tendo sido designado pelo próprio Borges como "poeta menor", Álvaro Lafinur ocupava posições estratégicas no campo literário em constituição, responsável pela seção "Letras Argentinas" (1912-1917) na revista Nosotros, o periódico mais representativo do establishment literário portenho, fundado em 1907 e cuja periodicidade com breve interrupção se prolongaria até $1943^{8}$.

Os mais destacados integrantes do círculo íntimo de amigos literários do pai de Borges - Carriego, Soussens e Lafinur - eram letrados típicos dessa geração finissecular, instada a prestar serviços compulsórios à grande imprensa diária, a cujos dirigentes buscavam se ligar. Esses magnatas lhes garantiam o sustento material, a posse momentânea de uma filiação institucional prestigiosa, salvo-conduto para o acesso aos espaços concorridos de sociabilidade, a um tempo mundana e literária, e as benesses de viagens e missões internacionais. Movendo-se num recesso de confrarias remuneradas, esses intelectuais podiam se entregar, de tempos em tempos, aos arroubos de uma veleidade - intentos com freqüência cerceados pelos deveres profissionais como jornalista -, dando vazão à energia autoral em revistas literárias ou na esporádica publicação em livro de versos e artigos já conhecidos. Aliás, a reputação desses letrados se deveu muito mais ao trabalho de resgate memorialístico, empreendido por amigos e admiradores, do que ao impacto exercido pelas obras. Tendo-se notabilizado por uma única obra de repercussão, ou então, pela expectativa algo fantasiosa de uma futura contribuição definitiva, da qual por vezes se conhecia até o título e o índice de matérias, como no caso paradigmático do extraviado "Le Château lyrique", de Soussens, esses letrados autodidatas produziram em resposta às diretrizes convencionais das revistas literárias da época e raramente em função de um projeto autoral reconhecível.

Borges foi se familiarizando com a vida literária pelo convívio com esses jornalistas letrados, em sintonia fina com os modelos europeus de fatura simbolista, muitos deles autodidatas que se prontificavam a exercer cargos e posições que requeriam um domínio seguro da escrita. Homens viajados, poliglotas, e como que "exilados" na Argentina, como Paul Groussac", por exemplo, os quais alicerçaram sua contribuição no manejo fluente de repertórios cultos, cuja raridade lhes assegurava proeminência num campo intelectual em gestação.
[6] Poeta e escritor, filho do político Ignacio del Mazo, amigo íntimo de Carriego, e autor de uma trilogia sobre o tango, muito elogiada por Borges.

[7] VerDiccionario de la literaturalatinoamericana, Argentina, parte I, pp. 101-102.

[8] Sobre as circunstâncias de funcionamento do emergente campo literário argentino no qual surgiu Nosotros, consultar o testemunho abalizado de um dos fundadores da revista, o crítico e historiador literário Roberto F. Giusti, Visto y vivido (anécdotas, semblanzas, confesiones y batallas) (Buenos Aires: Editorial Losada S.A., 1965), em especial as pp. 93-103, nas quais delineia um panorama da cena intelectual portenha no início do século XX, com seus cafés, cenáculos, teatros, temporadas de ópera, cinemas, exposições de arte, livrarias, padrões de atividade editorial, panteão nacional e internacional etc. Ver ainda Manuel Gálvez, Recuerdos de la vida literária (I), Amigos y maestros de mi juventud/En el mundo de los seres ficticios, com estudo preliminar de Beatriz Sarlo (Buenos Aires: Taurus, 2002, ed. original, 1944 e 1961). 
[10]Jorge Guillermo Borges: Hipoteca Naval, tese de doutorado apresentada à Faculdade de Direito e Ciências Sociais da Universidade Nacional de Buenos Aires em 1897, 63 pp., Buenos Aires: Tipo-Lito L. Franjoni); "El jardín de la cúpula de oro", conto inédito, sem data, 1908(?), conservado num exemplar da tese de doutorado deWenceslao C.Azevedo Laprida, tio da mãe de Borges; "Momentos (IIII)", Nosotros, X, 48, abr. 1913, pp. 147-148, poema; "Hacia la nada", Grand Guignol, 2, Sevilha, 10 mar. 1920, pp. 1-2, teatro; "El cantar de los cantares", Grand Guignol, 2, Sevilha, 10 mar. 1920, pp. 5-7; El caudillo, Palma de Mallorca: Imprenta Mallorquina de Juan Guasp Reinés, 1921, 195 pp. (reedição com prólogo de Alicia Jurado, pp. 11-23, Buenos Aires: Academia Argentina de Letras, 1989, 155 pp.); "Rubaiyat. Castellenizado del inglés de Fitzgerald por Jorge Borges",(1):Proa 2, 5, dez.1924,pp.55-57, tradução; Proa 2, 6, jan. 1925, pp. 6168. Ver Carlos García. El joven Borges, poeta (1919-1930) (Buenos Aires: Corregidor, 2000, pp. 211-307).

[11] «No me abandones en el destierro de la ciudad cuadriculada y de los jovencitos que hablan de la argentinidad y del civismo y de lo que significa el general Bartolomé Mitre para los siglos venideros.!Horror!Horror!», em carta endereçada ao amigo Jacobo Sureda, em março de 1921, reproduzida no volume Cartas del fervor (ed. cit., p. 194). O que mais o afligira às vésperas de retornar a Buenos Aires seria logo convertido em linha diretriz de suas preocupações como ensaísta da criollidad.
O mais complexo e matizado de seus relacionamentos nessa época envolveu a figura marcante do pai.Jorge Guillermo Borges (1874-1938), advogado praticante, professorde psicologia na Escola Normal para Línguas Modernas, era um homem culto e sofisticado, com domínio apurado da língua inglesa, tendo constituído uma biblioteca em cujo acervo se misturavam obras científicas, filosóficas, literárias, relatos de viagens, enciclopédias, livros de estampas, um mundo à parte em cujo interior sucedeu parcela substancial da socialização cultural do jovem Borges.

Entretanto, ressalte-se este componente decisivo na história da família, seu pai também parece ter nutrido, a vida toda, o desígnio persistente de uma carreira intelectual, como bem o demonstram alguns poucos poemas, a tese de doutorado, um conto, artigos em revistas de cultura e, em especial, uma novela que chegou a publicar em livro em $1921^{10}$, dois anos antes do livro de estréia do filho.

Junte-se ao desmonte de tais pretensões o flagelo de uma cegueira progressiva, cuja gravidade exigiu decisões familiares drásticas, como encetar uma prolongada viagem à Europa em 1914, no intuito de lograr a cura por meio de sucessivas intervenções, a experimentação de variados tratamentos e remédios, a consulta a especialistas afamados. E ressurge com nitidez o quadro das circunstâncias sofridas em que o jovem Borges foi como que "herdando" e assumindo como coisa sua um projeto frustrado do pai.

Suas cartas de juventude e as fotos de mocidade de Borges permitem vislumbrar os entusiasmos, as ousadias e os modos comportados de um rapaz de boa família, bem posto na vida, que teve de interromper os estudos por conta de atribulações familiares, às quais veio se juntar o anseio paterno, desejoso de atraí-lo para o ofício intelectual. O que mais impressiona é a quase inesgotável disponibilidade de tempo e recursos, que vão propiciando ao jovem Borges um sobreinvestimento em termos de aquisição e aprendizado de um fenomenal cabedal literário. A intensa "europeização" de Borges transparece no apuro do vestuário - sempre de colete e paletó, camisa de colarinho alto engomado, gravata com alfinete, ou laço borboleta, os cabelos repartidos e cuidadosamente penteados para trás - , bem como nos estereótipos externados a respeito dos compatriotas ${ }^{11}$, sintoma de sua decepção ao se deparar com um universo político e cultural acanhado quando do primeiro retorno em 1921.

Apesar de desnorteado por conta da deambulação dos seus, ao se haver com constantes mudanças de rotas, metas e sentimentos, as cartas de juventude permitem recobrar o quão intensamente Borges passou a vivenciar a vocação de escritor como tábua de salvação. Aentrega radical ao ofício literário, em meio a decepções e euforias, se fez acompanhar pelo tônus de esoterismo de que se revestem suas representações encantadas da atividade criativa. 
O nomadismo familiar, a busca constante de cura, as interrupções provocadas pelas inúmeras cirurgias, tudo isso deve ter infundido certa dose de suspense e irrealidade na educação dos filhos, como se tais circunstâncias negativas pudessem redundar em vantagens inesperadas, como um terreno de ousadia, um frescor de invenção, uma suspensão escapista das servidões terrenas, uma capacidade criativa mais atilada dele e de sua irmã Norah, dois anos mais moça, a qual tornar-se-ia mais tarde gravadora e artista plástica ${ }^{12}$. Como se sabe, Borges interrompeu os estudos após concluir o colegial em Genebra e não chegou a prestar o concurso para agregação em letras, num momento em que pensou em se tornar professor de inglês para poder se casar.

Aeducação de Jorge Luis e de Norah sucedera num regime um tanto segregado, mesmolevando-seem conta as condições peculiares em que se dava a formação escolar dos filhos de algumas famílias da elite argentina. Desejosos de lhes proporcionar um ensino que fosse superior ao vigente nos estabelecimentos da época, os pais contrataram uma professora particular estrangeira, a inglesa miss Tink, a qual ministrava diversas matérias em inglês. Nos anos em que a família Borges morou em Palermo, na casa da calle Serrano, vizinha à residência da avó paterna inglesa, Fanny Haslam, falava-se espanhol e inglês, e Jorge Luis era chamado pelo apelido de Georgie. Instalaram-se nessa rua em 1901 e nela residiram até 1914, quando viajaram pela primeira vez à Europa.

Georgie tinha quinze anos no momento da primeira viagem familiar à Europa, em fevereiro de 1914. A família residiu em Genebra até 1919, daí empreendendo inúmeros deslocamentos entre Madrid, Sevilha e Palma de Mallorca, entre 1919 e 1921. Por conseguinte, sua formação intelectual e literária ocorreu em meio a tumultuadas expectativas familiares no tocante às perspectivas de remediar a cegueira paterna. Muito embora as fontes disponíveis sejam reticentes, e bastante parcimoniosas a respeito da situação material da família Borges, pode-se aventar a hipótese de que, nesse projeto de vilegiatura européia para tratamento médico, o pai deve ter decidido lançar mão do pecúlio acumulado e da parcela patrimonial que lhe coube por herança ${ }^{13}$. O empenho de comentaristas e críticos e, em especial, as reiteradas alusões do próprio Borges, ao longo da vida, intentaram transmutar essas razões práticas em inclinações intelectuais, como se o pai de Borges tivesse desejado se afastar da Argentina para se consagrar por inteiro às atividades do pensamento, a uma prática reflexiva desinteressada, apenas acessível a um diletante dotado de recursos e de uma abundante disponibilidade de tempo.

A confiança inabalável do jovem Borges em seu potencial efetivo como intelectual sucedeu em meio à turbulência dos deslocamentos familiares, girando o tempo todo em torno dos avanços da cegueira, doença congênita que havia atingido seis gerações da família paterna,
[12]Leonor Fanny Borges (19011998), chamada Leonora, Nora e, ao que parece, mais tarde, a pedido do marido Guillermo de Torre, Norah. Macedonio Fernández costumava chamá-la de Leonorita, para diferenciá-la da mãe, dona Leonor.

[13] Ver Alejandro Vaccaro. Georgie (1899-1930), Una vida de Jorge Luis Borges. Buenos Aires : Editorial Proa/ Alberto Casares, 1996. Verdadeira mina de informações sobre a infância e a primeira mocidade de Borges, refere-se às casas de aluguel que a mãe de Borges, Isabel de Acevedo, havia recebido de herança. Essa biografia contém excelente documentação fotográfica sobre o jovem Borges e família. Para outras fotos, consultar Nicolás Helft e Alan Pauls. El factor Borges, nueve ensayos ilustrados. Buenos Aires: Fondo de Cultura Económica de Argentina, 2000. 
a qual, muito provavelmente, ele deve ter se dado conta, acabaria por se manifestar no seu caso. De fato, mais tarde, quase aos cinqüenta anos, após oito intervenções cirúrgicas, Borges ficaria cego, embora tivesse logrado até mesmo transmutar essa desgraça em matéria-prima de elucubrações em torno de certas peculiaridades de sua apreensão do mundo circundante.

Por melhor que tivesse transcorrido a prolongada primeira estadia dos Borges na Europa (1914-1921), pouco deve ter contribuído para sanar as fragilidades físicas do adolescente postulante à carreira letrada. Além do descolamento da retina quando criançae da necessidade de usar óculos desde pequeno, Borges padecia de uma gagueira da qual só conseguiu se livrarjá adulto. A piora da cegueira paterna parece ter sido concomitante ao destape da voz literária do filho. Quanto mais se inviabilizavam as pretensões intelectuais paternas, tanto mais estridentes as ousadias do emergente veio autoral de Borges. Enquanto a orfandade precoce do pai lhe obrigara a arranjar desde cedo uma profissão que the garantisse a sobrevivência, Borges foi tendo de lidar com uma espécie de orfandade diferida, na medida em que a cegueira paterna lhe infundiu um sentimento irrefreável de urgência no tocante à definição precoce de uma vocação literária. Tal decisão se fez secundar pela "opção" do celibato, pré-requisito que deve ter lhe parecido indispensável ao êxito de um projeto criativo de tal vulto.

A identificação de Borges com o pai lhe permitiu sondar e ajuizar as experiências de outros parentes e antepassados, que também haviam manifestado pendores literários. Existem indicações de que seu pai teria produzido muito mais do que o pouco que se conhece - originais que ficaram inéditos ou então destruídos pelo autor, entre os quais uma seleta deensaios, um livro de histórias orientais e um drama. Parece difícil dissociar as lendas a respeito do Borges pai como escritor bissexto da assunção, por parte do filho, das prerrogativas inerentes à sua posição de escritor bafejado pelos lampejos do recluso mago letrado. Havia, sem dúvida, uma interconexão perceptível entre, de um lado, a falência física e o esboroamento do projeto intelectual do pai e, de outro, a intensidade quase fervorosa com que o filho abraçou o ofício de escritor.

O quiasma desses dois itinerários foi transferindo energias e recursos do pai para o filho, tanto no plano dos trunfos familiares mobilizados, como em termos da convicção íntima de ambos quanto ao desfecho desses caminhos cruzados. Aliás, o confronto entre as fotos de Jorge Guillermo adulto e do jovem Jorge Luis revela fortíssima semelhança de traços - o rosto largo e ovalado, a testa imensa, os cabelos negros lisos e repuxados para trás, o pescoço carnudo, os olhos penetrantes - e sugere algum empenho do filho em arremedar o jeitão másculo do pai, como se os laços de continuidade pudessem ser tirados a limpo pela impressionante parecença física. 
O pai foi aos poucos abrindo mão das ambições literárias, acossado pelo avanço da cegueira, que já o atingira em cheio antes mesmo dos quarenta anos, justo no momento em que dispunha de alguma folga financeira. Os diagnósticos desencontrados e as sucessivas intervenções não lograram nenhum alívio e decerto aguçaram em ambos uma percepção distinta dos impasses: as frustrações paternas atiçando os dilaceramentos filiais.

Tamanha sintonia com a figura paterna remonta à primeira infância, quando Georgie se tornou bilíngüe, transitando com facilidade do espanhol — associado à linhagem materna, aos feitos dos militares evocados pela memória familiar - ao inglês, que lhe fora transmitido pelo pai e pela avó paterna, inglesa de origem. O espanhol lhe soava então como a língua inferior dos serviçais de seu país de origem; o inglês ostentava o status de língua culta, pulsante nos livros maravilhosos de poetas e viajantes, que podia consultar na biblioteca caseira.

Durante a temporada familiar na Suíça, Georgie aprendeu francês no colégio, que dominava por completo, na fala e na escrita, como atestam as cartas de juventude; e investiu ainda numa aprendizagem autodidata do alemão, da qual se saiu tão bem a ponto de ousar traduzir poemas expressionistas. Ao chegar a Madrid, quando a família decidiu iniciar o retorno por etapas, Georgie ficou surpreso ao constatar que os poetas espanhóis de sua geração liam os autores franceses em traduções e jamais no original, pois não dominavam nenhum outro idioma. Deve ter sido um dos primeiros choques no processo gradativo de auto-reconhecimento, como integrante poliglota de uma elite periférica de educação tão esmerada.

Por maior que fosse o valor da moeda argentina em 1914, Borges não pôde se equivocar quanto à condição material efetiva de sua família, tampouco se esquivar a compará-la à abastança de outros clãs argentinos em temporada européia naquela época. As mostras de uma progressiva tomada de consciência das injunções de sua situação social estão na raiz das hesitações do que pretendia fazer como intelectual: quais os gêneros que lhe atraíam como mais rentáveis, de maior repercussão, os temas que lhe incitavam o tirocínio político, os autores e obras que lhe permitiam achegas à atualidade política internacional - a Revolução Russa, a Guerra Mundial, as ideologias radicais.

Não resta a menor dúvida de que ele tentou com empenho e seriedade duas cartadas: o ofício poético, dando continuidade aos feitos dos modernistas hispano-americanos Darío, Nervo, Lugones sobretudo, sem esquecer os heróis líricos da infância, Almafuerte, Carriego e Banchs; o ensaísmo culturalista, de fundo politizado e messiânico, em formato inspirado em Schopenhauer, a influência decisiva sobre a intelectualidade espanhola em fins do século XIX e, por conseguinte, nos segmentos educados dos países hispano-americanos. 
[14] Ver E. Inman Fox. La crisis intelectual del 98 (Madri, Editorial Cuadernos para el Dialogo, 1976); Donald Shaw. La generación del 98 (Madri, Cátedra, 1997); José Luis Calvo Carilla. La cara oculta del 98 , místicose intelectuales en la España del fin de siglo (1895-1902) (Madri, Cátedra, 1998).

[15] Guillermo Juan Borges (19061965), chamado «Willie» ou «Willy», era filho do irmão do pai de Borges, o militar Francisco Eduardo Borges (1872-1940).
A formação intelectual de Georgie ocorreu num momento de crise aguda da sociedade espanhola, conjuntura marcada pela perda de Cuba, a última colônia na América, em meio à derrota sofrida na guerra com os Estados Unidos. A chamada geração de 98, da qual faziam parte alguns dos intelectuais reverenciados pelo jovem Borges, em especial Unamuno e Pío Baroja, emergiu nesse contexto e aí definiu a agenda de trabalho e a visão de mundo, norteadas pelo voluntarismo derivado do idealismo alemão ${ }^{14}$.

Ainda motivada pela recidiva da cegueira paterna, a segunda viagem dos Borges à Europa (1923) fora a tentativa derradeira de sustar o rebaixamento social como pior das ameaças. Nesse aperto, o jovem Borges herdou, paulatina e irreversivelmente, os haveres tangíveis e intangíveis do pai, a biblioteca, as disposições culturais sofisticadas, $\mathrm{o}$ domínio de línguas estrangeiras, as ambições literárias, as veleidades políticas do círculo de elite a que pertencia sua família, os fumos de um criollismo acendrado e, ainda, os amigos e as diversas modalidades de apoio que se revelaram indispensáveis ao deslanche bem sucedido da carreira de jovem tão promissor.

O fato de que a assunção de legado tão impressionante, desse cabedal invejável de trunfos complementares, tenha ocorrido em contexto propício à absorção de outras linguagens e repertórios expressivos, deve ter intensificado o apuro de suas habilidades no ofício literário. Essa mescla raríssima de elevado capital cultural como que aguçou a percepção sensível dos impasses a que estava exposto o pai, relativamente jovem e já compulsoriamente aposentado por conta da cegueira. Some-se a isso o acesso simultâneo a figuras estratégicas, de amplo trânsito no interior da elite nativa, dando liquidez às investidas ousadas do postulante.

Georgie foi educado num ambiente familiar consagrado à literatura, tendo sido, amiúde, encorajado em sua precoce vocação literária. Estava ciente desse suporte familiar, do apoio proporcionado pela rede de parentes e amigos que acompanharam o despertar e o amadurecimento de suas pretensões, bem como dos privilégios decorrentes dessa proximidade social de um círculo intelectual tão bem posicionado na cena cultural portenha. E a prova contundente dessa tomada de consciência pode ser aferida pelo exame dos seus empreendimentos mais ambiciosos no exercício de uma liderança inconteste naquela geração de vanguarda.

Assim, a fatura e a difusão dos manifestos de vanguarda se esclarecem no contexto de uma parceria familiar. A proclama divulgada no lançamento da revista mural Prisma, afixada nas paredes da capital argentina, em novembro de 1921, logo após o retorno da Europa, era também subscrita pelo primo irmão Guillermo Juan Borges ${ }^{15}$, filho do tio paterno, Francisco Eduardo Borges, único irmão de seu pai, pelo 
crítico espanhol Guillermo de Torre, futuro cunhado, e ilustrada pela irmã Norah Borges. A revista mural constituiu, de fato, uma iniciativa viabilizada, de cabo a rabo, pela chancela familiar. Afora o já citado manifesto, cujo mentor fora Borges, o mural incluía poemas do primo Guillermo Juan, e do amigo íntimo da estadia em Mallorca, Jacobo Sureda. A mãe emprestou baldes de cola, brochas e escadas para o trabalho no centro de Buenos Aires.

Ou então as antologias poéticas que teve a oportunidade de organizare divulgar na primeira mocidade, antes mesmo de haver estreado em livro. Os autores e os poemas selecionados constituem a resposta tácita aos apoios que vinha recebendo dessa rede de letrados com os quais partilhava afinidades de fundo e de forma. Em dezembro de 1921, Georgie publicou a antologia "Lírica argentina contemporânea" numa revista espanhola prestigiosa ${ }^{16}$. Assim como já fizera ao incluir um poema do primo Guillermo Juan na seleção de versos demonstrativos da estética ultraísta, encartada no artigo-proclama do novo credo estético, divulgado na revista Nosotros, em dezembro de $1921^{17}$, desta feita Georgie erige um panteão de poetas, referidos, em maioria, ao universo familiar de socialização literária.

A antologia se abre com um poema de Macedonio Fernández, "Al hijo de um amigo", que lhe fora dedicado, como que intentando lastrear uma linhagem literária cultivada em âmbito caseiro e confiada pelo amigo querido do pai à sua guarda, como líder inconteste da nova geração. Como Georgieé o objeto afetivo do recado, o poema seencerra com a louvação de sua figura como elo entre a geração emergente e a turma de letrados veteranos, da qual faz parte Macedonio, o autor da homenagem. Ressalte-se a razão invocada pelo mentor para comprovar o valor diferenciado de Georgie: a superioridade era afirmada pela cortesia do tratamento conferido às mulheres. Ora, Macedonio perscrutava atributos singulares do protegido na conduta de sociabilidade em vez de cravar seu cabedal em dotes de natureza intelectual.

Não tendo como reverenciar a obra de Macedonio, àquela altura ainda inexistente, quase toda inédita, mais alardeada do que tangível, Georgie elabora o escorço biográfico desse luminar nativo a partir das feições da personalidade excêntrica, salientando o prumo de polemista imbatível, a postura de ente filosofante, a prática extravagante de militante anarquista bissexto, os dotes de pensador ousado e original, o qual seimpôs muito mais pelavida do que pelas obras, pelos encantos da conversação, da expressiva oralidade, do jeito pessoal de tocar guitarra.

A seleção feita por Georgie reteve ainda versos de Marcelo del Mazo, primo de Macedonio e comensal dos domingos em Palermo, um soneto de Enrique Banchs, autor do livro de versos preferido do pai, e um poema do primo Álvaro Melián Lafinur ${ }^{18}$. Uma antologia referida quase por inteiro às coordenadas de suas experiências de
[16]Esta antologia foi publicada na revista Cosmópolis, Madrid, nㅇ 36 , dez.1921, reproduzida no volume já mencionado, Textos recobrados, pp. 132-141.

[17] Esta seleta de versos ultraístas constava do texto «Ultraísmo», Nosotros, Buenos Aires, ano 15, vol. 39, $\mathrm{n}$ ㅇ 151, dez. 1921, reproduzido no volume Textos recobrados, pp.126-131.
[18]Adiante, Borges redigiu uma resenha elogiosa, ainda que um tanto evasiva, das narrativas reunidas por Lafinur no volume Las nietas de Cleopatra (Buenos Aires: Gleizer), publicada na revista Valoraciones, La Plata, $\mathrm{n}-12$, fev. 1927, retomada no volume Textos recobrados, p. 283. 
[19] As resenhas de 1919 saíram em $L a$ Feuille. Journal d'Idées et d'Avant-Garde, II, 306, 20 ago.1919, p. 6; os trabalhos de 1920-1921 foram difundidos nas revistas Grecia, Gran Guignol, ambas de Sevilha, no jornal Última Hora enas revistas Baleares (Palma de Mallorca), Cervantes, Ultra, Tableros e Cosmópolis (Madri). socialização literária, como que um acerto visando retemperar afinidades por meio de contraprestações, marcadas pelo espírito de clã e pelos juízos personalistas e idiossincrásicos do jovem Borges, desejoso de retribuir préstimos e equilibrar trocas nessa parceria.

Interpreto o ensaísmo borgeano dos anos 1920 como fruto da curiosidade em apreender, de dentro de um universo de tradições culturais, as peculiaridades de uma condição social e política periclitante. Na medida em que os trunfos de linhagem e de antigüidade na classe dirigente não conseguiam sustar a rápida deterioração das expectativas de futuro social dele mesmo e dos familiares, a qual tendeu a se acelerar tanto mais por força da invalidez paterna, Borges mergulhou por inteiro na atividade intelectual. Era o único escape, a saída honrosa ao alcance de um jovem brilhante, cujas perspectivas de promoção classista se haviam embaçado por conta dos impasses familiares.

Entre fins de 1919 e o primeiro trimestre de 1921, com vinte e poucos anos, Borges realizou uma produção intelectual de envergadura para a sua idade, testando habilidades num espectro diversificado de gêneros e formatos expressivos. Em 1921, ano miraculoso em matéria de produtividade literária, Borges escreveu poemas e prosas poéticas, resenhas e diatribes, contos curtos, ensaios e manifestos, realizou traduções de poesias alemãs ${ }^{19}$.

As viagens do clã Borges teriam assim lhe propiciado a oportunidade rara de iniciação prática e com riscos elevados em diversas frentes da atividade intelectual, como que glosando, ao seu modo, os gestos pregressos de atrevimento paterno, ou então, o que dá no mesmo, os reptos da criatividade paterna que ele reelaborou em chave cada vez mais idealizada à medida que envelhecia. Não estava ao alcance de qualquer um, àquela fase da mocidade, poder transitar entre o ensaio crítico, com intentos de intervenção estética e doutrinária, o virtual domínio técnico de outras linguagens e estilos expressivos por meio de traduções, a militância petulante em revistas de vanguarda, a fatura poética audaciosa e o exercício desaforado da liderança intelectual.

No curto período de estadia em Buenos Aires, entre as duas viagens à Europa, Borges parece ter se apaixonado e ficado quase noivo de Concepción Guerrero, dando mostras de querer estabilizar-se no plano profissional. Conhecera a noiva em casa da família Lange, da qual era aparentado por intermédio do tio militar. Pensou em se tornar professor de inglês, a fim de garantir o sustento, plano que por si só esclarece as perspectivas travadas do futuro que então conseguia vislumbrar. Não soa, pois, tão descabido aventar a hipótese de que uma das finalidades tácitas da segunda viagem familiar teria sido apartá-lo da amada, fazê-lo esquecer tal envolvimento, convencê-lo dos engui- 
ços a que se expunha um jovem com tantos embargos, no intuito de que não descurasse da atividade intelectual como meta central de vida.

As viagens familiares, encetadas por razões práticas imperativas, quase todas ligadas à busca por socorro médico capaz de reverter a galopante cegueira paterna, foram sendo repensadas por Georgie como percurso iniciático. Tal itinerário encantado lhe propiciou inflaros propósitos dessa "vocação" insuflada pelos familiares, pelos amigos próximos do círculo doméstico e, ao fim e ao cabo, cultivada por ele mesmo, com requintes de autodidata excêntrico. Nessa movida de energias se confundiam os intentos paternos, imperativos e compensatórios, e os empenhos do herdeiro ao se apropriar dos haveres do pai e da família.

Tudo se passa como se o projeto literário de Borges tivesse se viabilizado por incitações derivadas de uma confluência excepcional de expectativas dos seus, convertidas em pulsões próprias, a começar pelos desígnios projetivos do pai, atiçados pelas esperanças difusas manifestadas pelos demais parentes letrados, pelos escritores que freqüentavam sua casa, até a adoção do jovem tão promissor por parte de amigos chegados do pai, quase como o objeto dileto de seus investimentos afetivos e intelectuais. $O$ fecho dessa herança presuntiva, trabalhada de parte a parte, consistiu no financiamento paterno do livro de estréia de Georgie, cuja impressão de uma tiragem de trezentos exemplares custou 130 pesos.

O caso Borges atesta a seu modo o papel estratégico desempenhado pelo declínio material e político de certas famílias desse setor criollo empobrecido da elite argentina, nas quais foram recrutados alguns integrantes destacados da primeira geração da vanguarda. A vanguarda portenha reuniu jovens de famílias ilustres - alguns até endinheirados, em estágios variáveis de retrocesso econômico — aos filhos de famílias de origem imigrante. Os moços criollos preferiram se consagrar aos gêneros elevados, a poesia e o ensaio, ao passo que os descendentes de imigrantes se arriscaram na prática de novos formatos literários como as crônicas, as reportagens, a crítica militante de livros, filmes e espetáculos, os folhetins, e os relatos ficcionais curtos. O diferencial dessas propensões era decerto o manejo desempenado e altivo da língua pátria por parte dos herdeiros criollos.

Enquanto Borges, Girondo e Bernárdez teimavam em testar os dotes expressivos na inovação de gêneros legítimos, a poesia e o ensaio, Arlt, por sua vez, se aventurou em novos feitios paraficcionais, a meio caminho entre a reportagem, a chaga viva do documento, e um fio mais ou menos esquálido de trama romanesca. Osvanguardistas de boa cepa infundiam aos escritos os prumos estrangeirados e a substância do aprendizado europeizante. Os contemporâneos de procedência imigrante permaneciam atados às agruras desse itinerário atribulado e não conseguiam sequer nublar a memória dessa carga de humilhações na transcrição literária da história sofrida de suas famílias. 
[20]A tese de Macedonio se intitulava De las personas, feita sob a orientação de Carlos Malalagarriga, jornalista e jurista espanhol então exilado em Buenos Aires devido a atividades republicanas, tradutor de Bergson. Ver Álvaro Abós. Macedonio Fernández, la biografía impossible. Buenos Aires: Plaza \& Janés, 2002.

[21] Entre os letrados consagrados dessa turma, destaca-se Enrique Rodríguez Larreta (1875-1961), novelista, poeta, dramaturgo e ensaísta argentino cuja reputação se firmou com a novela histórica La gloria de Don Ramiro, una vida en los tiempos de Felipe II (1908). Ver Diccionario de la literatura latinoamericana, parte II, cit., pp.311-315.

[22] A partir de 1901, a família Borges residiu nessa rua, primeiro em casa (no 2135) de propriedade da avó paterna, Fanny Haslan, em seguida numa casa nova ( $\mathrm{n}$-2147) que mandaram erguer num lote vizinho.

[23] Alguns dos textos mais antigos constam do primeirovolume das obras completas de Macedonio Fernández, Papeles antiguos (Escritos 1892-1907), Datos para una biografia. Bibliografia Completa (Buenos Aires: Corregidor, 1981).
PADRINHO EXCÊNTRICO (MACEDONIO FERNÁNDEZ)

\section{E APRENDIZAGEM DE ESTESIAS}

O exame das relações entre o jovem Borges e o letrado Macedonio Fernández permite recuperar uma segunda fornada de energias propulsoras do dispositivo vocacional borgeano. Nascido em Buenos Aires no mesmo ano de seu pai, filho de um estancieiro, Macedonio foi colega de turma e amigo íntimo do pai de Borges, tendo freqüentado juntos o Colégio Nacional de Buenos Aires no secundário e, mais tarde, a Faculdade de Direito e Ciências Sociais da Universidade de Buenos Aires, na qual ambos se formaram e defenderam a tese de doutorado, em $1898^{20}$. Pertenceram a uma turma famosa da faculdade, a qual incluía nomes ilustres que se tornaram figurões da economia, da política e da cultura argentinas ${ }^{21}$. Além dos diversos amigos em comum, o pai de Borges freqüentava a casa dos pais de Macedonio, local de encontro de políticos e homens de letras, muitos dos quais participaram da criação do Partido Socialista em 1896. O modo de funcionamento desses encontros deve ter contribuído para as feições de sucessivos círculos de amigos letrados que se organizaram em torno da tutela exercida por Macedonio.

Julio Molina y Vedia, outro integrante das tertúlias, herdeiro de uma dinastia de grandes proprietários de terras, também amigo do pai de Borges, interessado em filosofia eliteratura, era arquiteto, o responsável pela construção da casa dos Borges na calle Serrano ${ }^{22}$, revestida com elementos artnouveau na fachada. Jorge Guillermo viria a resenhar um livro de poemas de Julio, em 1929. Macedonio, por sua vez, comparecia com regularidade às tardes de domingo na casa dos Borges.

Entre os tempos de universitário e os primeiros anos da década de 1920 , quando começam a ser divulgados alguns de seus textos em revistas de vanguarda, a produção intelectual esparsa de Macedonio se assemelha em toda linha àquela do pai de Borges: ensaios sobre costumes e logradouros argentinos, sonetos bissextos, escritos filosóficos de esotérico teor metafísico, sem falar do aceso interesse de ambos por psicologia. Macedonio tinha gosto em conceber aforismos e reflexões inusitadas, mesclando tais lampejos com citações de leituras em seus cadernos. Entre 1897 e 1920, ou seja, entre os 23 e os 46 anos de idade, Macedonio produziu apenas alguns poemas eartigos, tendo firmado presença quase mítica muito mais por intervenções orais, pela fluência e pelas tiradas de sua conversa, pela boa estrela de sua imagem entre os amigos ${ }^{23}$.

Ao emitir o juízo de que "o talento de Macedonio era eminentemente verbal”, Borges contribuiu para a tendência crítico-historiográfica de apreender o veterano letrado como conversador de primeira, tornando esse virtuosismo, em meio aos embates da oralidade, uma forma sutil de detração dos dotes como escritor. $\mathrm{O}$ 
fundo de verdade nessa aposta borgeana pode ser atestado pelo exame de certas modalidades de sua expressão literária nos dois livros publicados no final dos anos $1920^{24}$.

Assim, em Papeles de recienvenido, os breves escorços autobiográficos nos quais infunde uma tagarelice afetada, permeada por uma reflexividade ácida e auto-irônica, deixam aflorar lampejos de auto-representação, como a declaração de pertença às antigas famílias criollas, os olhos azuis como faiscante traço recessivo do rentista discreto. Esse mesmo volume comporta falas e improvisos pré-fabricados, enunciados em jantares comemorativos, de homenagem a escritores eartistas amigos ("Brindis de recienvenido"), um epistolário endereçado aos amigos íntimos ("Correo casero de recienvenido"), sem falar da "Miscelânea" ao final do livro e das centenas de revelações íntimas eufemizadas naqueles textos em que se misturam arroubos filosofantes, intervenções jornalísticas, poemas e contos dedicados à esposa morta. Advogados atuantes, especialistas em psicologia, casados, na mesma época, com mulheres procedentes de famílias prestigiosas $\mathrm{da}$ elite nativa, Jorge Guillermo e Macedonio também desfrutavam de acesso aos mesmos espaços de sociabilidade da nata de bacharéis: 0 Jóquei Clube, as festanças comemorativas da formatura em direito, as temporadas de verão nas propriedades de parentes. Ao que tudo indica, Macedonio deve ter se correspondido com Jorge Guillermo durante a estadia dos Borges na Europa, o que permitiu ao jovem Borges seguir de perto as peripécias políticas eespirituais dessa espécie de mago politiqueiro iniciado nos recessos da psique humana.

Os traços que o distinguiam devem ter impressionado um bocado Borges, a começar pelas investidas políticas de Macedonio, que teria chegado a ponto de externar a pretensão de lançar-se candidato extrapartidário à Presidência da República nas eleições vencidas por Marcelo de Alvear. Gozação ou intento frustrado, tal projeto foi levado tão a sério por todos os circunstantes, que acabou por integrar-se ao anedotário canônico sobre Macedonio. Conforme dão a entender as cartas trocadas com o primo e confidente, Marcelo del Mazo, essa aventura - para a qual mobilizou uma legião de amigos, inclusive o pai de Borges, então em Madri, e na qual fica difícil deslindar a realidade da fabulação - alimentou sucessivos projetos literários, desde a novela projetada em colaboração com o jovem Borges 25 , até a fatura caprichosa do personagem presidencial em sua novela mais ambiciosa, publicada muitos anos depois ${ }^{26}$.

Macedonio foi se convertendo num duplo da figura paterna, réplica positiva e isenta das deficiências do modelo, encarnada num vulto de homem com traços análogos de geração e de classe. Tais vantagens decerto lhe infundiram o desejo de assumir a missão de como que perfilhar o jovem Borges, quer em termos de sociabilidade, quer
[24] Macedonio Fernández: No todo es vigilia la de los ojos abiertos (Buenos Aires: Manuel Gleizer, 1928); Papeles de recienvenido (Buenos Aires: Cuadernos del Plata, 1929).
[25] Trata-se da novela El hombre que será presidente, projeto comum de Macedonio e Jorge Luis por volta de 1921, referido nas cartas trocadas entre ambos, publicadas no volume já mencionado.

[26] Macedonio Fernández.Museo de la novela de la eterna. Buenos Aires: Centro Editor de América Latina, 1967 , edição póstuma. Republicada em 1975 pelas Ediciones Corregidor, no volume VI das obras completas e em 1982 em Caracas, na Biblioteca Ayacucho. Ver a edição crítica coordenada por Ana María Camblong e Adolfo de Obieta, escritor filho de Macedonio (Edusp/Coleção Archivos, 1996,591 pp.). 
em chave literária, como fez questão de registrar no poema "Al hijo de un amigo", composto nessa época e de pronto acolhido pelo homenageado na antologia mencionada. Os versos de abertura nessa composição ungem o jovem Borges como o messias em defesa da doutrina do projeto abortado pela geração dos veteranos.

Essa paternidade vicária foi assumida pelo escritor bissexto e pelo pupilo, com conseqüências de peso para a imagem pública e a fortuna crítica do padrinho literário e existencial, incensado como precursor do Borges maduro e realizado, dando margem a certo rearranjo do panteão literário argentino. Borges precisava dessa mexida de posições: entronizar Macedonio como o mestre da geração inovadora equivalia a derrubar Lugones do pódio prevalecente na década de 1920. O empenho em alardear a oralidade criolla de Macedonio, tanto por parte do jovem Borges como pelos vanguardistas da revista Martín Fierro, dotou-o de uma efígie enigmática, homem misterioso, que teria se afastado dos familiares e dos círculos exclusivos em que fora educado, notabilizado por idiossincrasias e tiques do argentino de alta estirpe. Macedonio seria quase a antítese do escritor convencional festejado, como Lafinur, outro arrimo de Borges.

Não tendo jamais pisado em algum país europeu ou latino-americano, Macedonio foi se conformando às feições do eterno "recienvenido", candidato plausível e, a um tempo, inviável como liderança política ou ideológica, uma referência emblemática no cultivo dessa mística do criollo que se basta a si mesmo. Tocava guitarra, apreciava os românticos alemães e os prelúdios de Rachmaninoff, vivia trocando de pensão ou residindo em casas afastadas do centro, cultivando as manias e as maquinações do gênio recluso.

O rentista Macedonio Fernández del Mazo conseguia sobreviver da venda de terras no campo e de terrenos na capital, uma calculada dilapidação do patrimônio familiar. Apesar das feições narrativas pouco convencionais do famoso relato autobiográfico, de 1929, as esparsas achegas do livro manejam esses fumos de prestígio por meio de predicados inerentes à sociabilidade oligárquica, tendo logrado acionar os recursos expressivos que lhe permitiram simular o rechaço do cotidiano reprodutor de seu grupo de origem. O Macedonio de olhos azuis, que redigia cadernos secretos de reminiscências, nunca divulgados, tomava matee acolhia os amigos nos cômodos escuros em que morava, cultuando a conversa, o humor, as tiradas paradoxais, as charadas, numa curtição inveterada da "amizade" como credo existencial.

As excentricidades de Macedonio em diversos domínios, que se haviam intensificado após a viuvez em 1920 - a troca constante de locais de residência, as paixonites por prostitutas, um trem de vida inusitado para o ramerrão burguês - como que avivaram em Borges a empatia pelo personagem e o interesse crescente por seus escritos. Borges acabou 
enxergando-o como uma espécie de pai substituto, ou melhor, o sucedâneo senhor de si, sem os óbices paternos, igualmente imaginativo, mas destrambelhado, propenso a condutas intempestivas e surpreendentes.

Macedonio se correspondeu com o filósofo francês Arréat em torno da substância do ego e, por quase seis anos, com o filósofo norte-americano William James. Depois de formado, ele e outros colegas, entusiastas do ideário socialista romântico, inspirado em Lasalle e SaintSimon, tentaram estabelecer uma comunidade utópica e anarquista numa ilha selvagem do Paraguai - em terras pertencentes à família Molina y Vedia - , primeira evidência do interesse candente pela atividade política. A exemplo do pai de Borges e de tantos bacharéis e letrados dessa geração nos países latino-americanos, leitores convictos de Spencer e infensos aos poderes do Estado, Macedonio se enquadrava no perfil dos membros da elite dirigente de livres pensadores e anarquistas, atentos aos grandes acontecimentos do momento.

Por conta desses ligamentos, não é de se estranhar que o jovem Borges tenha se afeiçoado a Macedonio e o tenha convertido em modelo de excelência "clandestino". Nos primeiros anos dessa amizade um tanto assimétrica, o mestre "subterrâneo" e o discípulo "afilhado" apreciavam os mesmos filósofos - em especial, Schopenhauer -, e partilhavam tantas afinidades políticas que formularam o projeto, jamais encetado, de escrever uma novela fantástica que abordaria os meios empregados pelos maximalistas - a multiplicação de muitas pequenas moléstias - para provocar uma neurastenia geral em todos os habitantes de Buenos Aires e abrir assim caminho ao bolchevismo.

Com o regresso dos Borges em 1921, e sob a instigação maravilhada de Jorge Luis pelo quase mítico guru e por seus escritos, Macedonio se incorporou à vida literária portenha, colaborando em diversos periódicos e ampliando o rol de fervorosos jovens admiradores na vanguarda. Em 1927, Macedonio deve ter instado Borges a aderir à candidatura de Hipólito Yrigoyen, tendo ambos participado do Comité Irigoyenista de Intelectuales Jóvenes. Os dois primeiros livros de Macedonio foram editados no final dos anos 1920, o primeiro deles custeado pelo autor, numa tiragem de apenas duzentos exemplares, $\mathrm{O}$ segundo com selo das edições Proa ${ }^{27}$.

Macedonio também fez as vezes de intermediário entre Borges e os intelectuais veteranos da geração precedente, os quais detinham o controle dos principais periódicos e empreendimentos editoriais de vanguarda, como as revistas Proa 2 eMartín Fierro e a Editorial Proa. Refirome ao condomínio de interesses e frentes de investimento envolvendo Evar Méndez, Ricardo Güiraldes e Oliverio Girondo, esse último o único da geração de Borges. Num campo intelectual ainda em gestação, como o argentino, no qual a fortíssima ingerência do poder econômico deixava espaço restrito aos rompantes de autonomia por parte de seus
[27] Macedonio Fernández, No todo es vigilia la de los ojos abiertos, ensayo metafisico e Papeles de recienvenido. 
integrantes, mesmo daqueles mais trunfados social eintelectualmente, a proteção conferida pelos grandes investidores - tanto mais valiosa quando esses empreendedores exerciam em paralelo uma atividade literária, como nos casos de Güiraldes e Girondo - constituía a moeda decisiva das relações de força e de sentido naquele universo restrito de trocas. Macedonio aproximou Borges dos figurões no universo literário argentino da década de 1920. De imediato, Borges soube consolidar laços de amizade com cada um deles, passando a colaborar na revista dirigida por Girondo e Evar Méndez, tornando-se parceiro de Güiraldes e Evar Méndez no projeto da Editorial Proa e, por fim, ajudando a promover a empreitada latino-americanista dos martinfierristas liderados por Girondo em sua viagem de 1924 .

As diversas intervenções no debate em torno dos graus de originalidade de Macedonio acabaram por ricochete se transmutando em indagações a respeito de Borges como plagiário de Macedonio. Daí em frente, ao longo de toda a vida, Borges jamais deixou de endossar as influências recebidas de Macedonio, os empréstimos sucessivos de seus achados, aforismos, reinações, de seu léxico chacoalhado por significações forjadas. Em retrospecto, a interação tão estratégica de Borges com Macedonio lhe permitiu testar expectativas e intentos, como pretendente trunfado à carreira intelectual entre os muitos egressos dos antigos ramos da elite argentina, como integrante de uma família orgulhosa de sua linhagem, dos feitos militares e políticos dos antepassados, buscando guarida num modelo de escrita pouco convencional, fora dos parâmetros daquela geração. Tal exemplo lhe proporcionou um modelo de intelectual destoante, de leitura difícil, cujos atributos mais ostensivos procediam de uma inserção social acidentada, e não de uma prática intelectual profissional.

O convívio próximo com Macedonio lhe permitiu uma sondagem mais distanciada do imaginário e dos padrões de sensibilidade dos círculos sociais a que pertenciam aquelas famílias criollas. Esse relacionamento lhe espicaçou o empenho em discernir os impensados e as excentricidades daquela mentalidade, em deslindar os meandros de suas preferências políticas e doutrinárias ou os esquadros de apreciação da tábua de valores do que se considerava então autenticamente "argentino". Macedonio fez a ponte entre a primeira socialização familiar, demasiado turvada pelos sentimentos tumultuados de Borges diante dos reveses familiares, e a tomada de rumos para uma carreira intelectual em sintonia com seus "iguais".

A recepção crítica favorável a Borges, desde a arrancada de sua trajetória intelectual, ao longo dos anos de 1920, deveu-se às relações privilegiadas que logrou estabelecer com os letrados veteranos da geração paterna - Macedonio Fernández, Evar Méndez, Ricardo Güiraldes, Roberto Giusti - e também com lideranças de peso na cena cultural 
espanhola e latino-americana. Primeiro com o poeta Rafael CansinosAssens, os ensaístas Ramón Gomez de la Serna e Guillermo de Torre, logo adiante Ortega y Gasset, Alfonso Reyes e outros nomes destacados do establishment cultural e literário hispano-americano. A rigor, o único companheiro de geração literária que mereceu sua atenção foi Oliverio Girondo, por razões que pouco têm a ver com as preferências literárias ou pessoais de Borges. A caracterização desses letrados pertencentes ao círculo do pai de Borges, em especial Macedonio Fernández, propicia um flagrante matizado da rede de interdependências a que estavam conectados, naquele espaço social trincado pelas incertezas quanto ao futuro dessa fração da elite argentina, detentora de um superavit de capital cultural que lhe permitiria infundir energias explosivas na modelagem do projeto criativo de seus herdeiros.

Borges adquiriu prontidão técnica e ideológica por meio desse círculo de letrados, o qual fazia as vezes de microcosmo vibrante do universo de interações ao alcance de seus calouros. Não se podem descarnar os desígnios doutrinários dos primeiros livros, tingidos a cada página pelos ideais e ruminações queixosas daqueles homens cultos criollos, relegados pela nova dinâmica de oportunidades econômicas, nostálgi$\cos$ da herança prestigiosa das antigas gerações familiares, tão orgulhosos dos políticos, militares e periodistas, entre seus ilustres antecessores. Não foi por acaso, capricho ou apenas vontade própria que Borges se empenhou com garra nesse estrondo expressivo. Sua primeira década como escritor altamente produtivo evidencia o intento de assumir a dianteira como ideólogo traquejado, capaz de viabilizar a redenção dos valores conservadores, sob ameaça iminente de serem desfibrados.

Na tentativa de fundir, nessa prática poética eensaística, a bandeira patriótica e o estro lírico tão fortemente associado às figuras de Banchs e Almafuerte, o jovem Borges quis por à prova o calibre de seu cabedal, então a serviço de um programa recessivo, o qual pudesse trazer alento, ou ao menos sustar o esvaimento das pretensões de influência política dos círculos criollos a que pertenciam ele próprio e todos os seus. A apreensão do caráter, do estilo e da substância temática das obras dos anos 1920 deve, pois, estribar-se no resgate dos laços íntimos do estreante Borges com esses setores, no interior dos quais ele foi socializado e, no limite, convencido quanto à legitimidade e à urgência das palavras de ordem de sua redenção. Tais experiências modelaram as feições e os feitos extraordinários desse talento fulgurante, como que empurrado, alçado mesmo, desde os escritos de juventude, à condição privilegiada de porta-voz e herdeiro das "iluminações" alardeadas pelos mentores e patronos.

Girondo, Borges e Bernárdez ${ }^{28}$ foram alguns dos escritores vinculados à vanguarda martinfierrista que, de fato, se formaram em contato e proximidade com as propostas de renovação da cultura européia no
[28] Oliverio Girondo. Obras/Poesía (8a ed. Prólogo de Enrique Molina. Buenos Aires: Editorial Losada, 1998); Jorge Schwartz. Vanguarda e cosmopolitismo na década de 20: Oliverio Girondo e Oswald de Andrade (São Paulo: Perspectiva, 1983); Homenaje a Girondo (Buenos Aires: Corregidor, 1988); Rogelio Barufaldi. Francisco Luiz Bernárdez (Buenos Aires: Ediciones Culturales Argentinas/ Ministerio de Educación y Justicia, 1963); Diccionario de la literatura latinoamericana (parte II, verbete sobre Bernárdez,pp. 245-247). 
período de entreguerras. Eles tiveram o privilégio de empreender, no mais das vezes em companhia de suas famílias, sucessivas viagens à Europa. O envolvimento crescente com linguagens e procedimentos das vanguardas locais, em especial na França e na Espanha, mas também na Alemanha e na Itália, abriu-lhes oportunidades de veicular seus textos em revistas européias, e ainda lhes propiciou uma reação crítica favorável naqueles espaços estratégicos de difusão. A vocação literária de todos eles resultou, portanto, do embate entre constrições contrastantes: de um lado, as expectativas dos círculos sociais e intelectuais a que pertenciam na Argentina, as obras e os autores festejados daquela tradição cultural, a agenda de temas e prioridades derivados de uma dada conjuntura histórica; de outro, os modelos de inovação estética e literária em vigência na cena européia de vanguarda.

Nas condições de operação do campo literário argentino nos anos 1920 e 1930, em lugar de priorizar o significado estético das iniciativas e obras dessa geração de vanguarda, os arroubos criativos de juventude se tornam inteligíveis nos marcos da socialização desses "herdeiros", em especial nos casos exemplares de Girondo e Borges, impregnados por completo pelo universo de valores, padrões de gosto e expectativas de suas famílias, ou seja, dos círculos de elite em que se modelaram tais projetos intelectuais. Basta atentar às inúmeras modulações com que Borges intentou manejar o gênero biográfico, a começar pelo experimento multifacetado que desaguou no ensaio Evaristo Carriego, para nos darmos conta da incessante reciclagem de sentidos a que foi tentando sujeitar os retratos hirtos dos antepassados, os relatos memorialísticos das grandes figuras do Centenário, mesclados às representações personalizadas de personagens prensados, literalmente, entre a legenda histórica, a memória familiar e de classe, e o enredo ficcional.

Fervor de Buenos Aires foi recepcionado por uma dúzia de resenhas, na Argentina e na Europa, algumas delas subscritas por escritores de certa reputação, como Enrique Díez-Canedo, Salvador Reyes e Ramón Gomez de la Serna, este último tendo publicado a sua na prestigiosa Revista de Occidente. O livro seguinte de Borges, Inquisiciones, mereceu resposta de voltagem idêntica, tendo feito jus a resenhas em periódicos locais e àquelas assinadas por Cansino-Assens, Guillermo de Torre e Pedro Henríquez Ureña em publicações espanholas. Luna de Enfrente, o segundo livro de versos, suscitou resenhas pelos companheiros de maior prestígio na turma vanguardista - Bernárdez e Marechal -, além do artigo firmado pelo crítico e futuro cunhado, Guillermo de Torre, outra vez na Revista de Occidente. Tais reações garantiram a Borges um cabedal invejável de prestígio, um lugar de primazia, abrindo-lhe oportunidades e iniciativas que ele jamais poderia ter sem respaldo dos veteranos, os quais lhe permitiram calçar uma posição de força no comando da geração argentina de vanguarda. 
Da perspectiva daqueles círculos letrados, nenhum dos registros, proclamas e tomadas de posição assumidos pelo jovem Borges soava de todo como novidade. A geração intelectual precedente, a do Centenário, vinha batendo naquelas teclas doutrinárias com que se aprumaram as principais frentes de combate ideológico e cultural. Num momento de crise e de baixa do prestígio político e simbólico da Espanha após a humilhante derrota sofrida diante dos Estados Unidos, os intelectuais hispano-americanos haviam cerrado fileira em torno da defesa do hispanismo, alardeando a centralidade espiritual da alma mater da ex-metrópole e forjando um linguajar de nomeação dos laços preferenciais. $\mathrm{Na}$ Argentina, os escritores veteranos haviam realçado a linha divisória entre nosotros, os argentinos de pura cepa espanhola, descendentes dos antigos colonizadores, os verdadeiros criollos, donos legítimos do país, eellos, os imigrantes adventícios, potenciais diluidores da identidade criolla. A língua espanhola era o suporte quase místico dessa comunhão de valores, tanto mais exaltada quanto maior a concorrência que lhe faziam os idiomas falados pelos imigrantes, ou pior, os dialetos mesclados como o cocoliche ou o lunfardo.

Em contraponto ao influxo irresistível dos imigrantes como força social "dissolvente" do caráter argentino idealizado, o gaúcho incensado como alicerce da "argentinidade" fora associado a um passado nacional anterior ao fluxo migratório, às reformas educacionais e eleitorais empreendidas pelos dirigentes da República liberal e, mais importante de tudo, à predominância da agricultura intensiva de exportação como ponta de lança de um novo estágio de integração da economia argentina no capitalismo.

Nessa atmosfera política e cultural de resistência às transformações em curso no plano econômico, propagadas nas feições renovadas do sistema político-eleitoral e nos lineamentos de uma estrutura social em ebulição, a nova geração da vanguarda literária não conseguiu se esquivar dos sentimentos ambivalentes de rancor e ressentimento, os quais pareciam predominar em certos círculos declinantes da antiga elite criolla de onde procedia a maioria de seus integrantes. Os poemas e ensaios de Borges dos anos 1920 se enquadravam, pois, nesse prumo afinado com os desafios e questionamentos suscitados pelo criollismo ${ }^{29}$. Em meio às rivalidades geracionais, as ameaças à sobrevivência desse legado nacionalista estavam a exigir uma defesa desabrida e consistente das linhagens e obras representativas da literatura gauchesca, uma revisão corajosa do passado histórico ajuizado pela ideologia modernizadora dos liberais e, no tranco, um resgate simbólico do mundo social de um setor de classe sitiado, o qual se sentia acossado pelos imigrantes emergentes.

\footnotetext{
[29] A respeito das obras do jovem Borges, consultar as análises empreendidas porVíctor Farías: La metafísica del arrabal (Madri, 1992); Las actas secretas, Inquisiciones y El idioma de los argentinos, los otros libros proscritos de Jorge Luis Borges (Madri, Anaya \& Mario Muchnik, 1994); e Rafael Olea Franco. El otro Borges. El primer Borges (Buenos Aires : Fondo de Cultura Económica de Argentina, 1993). Embora ambos os autores recorram sobretudo a modelos filosóficos e de crítica literária genética, logrando assim formular interpretações ao arrepio de constrições sociológicas, suscitam indagações valiosas e lançam pistas de ligamentos até então insuspeitos.
} 
[30] Consultei exemplares da edição original de Fervor de Buenos Aires e Inquisiciones, conservados na seção de livros raros da biblioteca da Universidade de Stanford, que tive a oportunidade de freqüentar durante minha estadia como fellow do Center for Advanced Studies in the Behavioral Sciences entre 2001 e 2002 .
Ao contrário do que postula certa literatura promocional da vanguarda literária argentina, o jovem Borges nunca esteve confinado às revistas de vanguarda e, desde os primeiros tempos do retorno a Buenos Aires, fora convidado a colaborar em diversos es paços controlados pelo establishment literário portenho. A maturação desse relacionamento culminou com o convite para assumir uma coluna mensal no diário La Prensa. A intensa circulação no interior do campo intelectual e jornalístico argentino contribuiu decisivamente para realçar o impacto de seus escritos, divulgados, quando calhava, em jornais e periódicos vinculados aos grupos dirigentes.

A leitura atenta dos livros de estréia de Jorge Luis Borges, nos dois gêneros em que exercitou os pendores nacionalistas - a poesia e o ensaio - permite apreender a teia de significados que infundiu em seus escritos e na militância intelectual à testa do movimento de renovação literária na década de 1920 . Fervor de Buenos Aires ${ }^{30}$ e Inquisiciones são livros aprontados em sintonia apurada, lances complementares de um mesmo projeto intelectual e político, a serviço de desígnios idênticos de revigoramento de uma identidade criolla autêntica e no qual se reconheciam os círculos da elite cultivada aos quais estava endereçado.

O cerne do argumento nacionalista do jovem Borges está patente na versão revisionista da história pátria, ora ministrada em versos nativistas, em preitos de homenagem a heróis familiares, ora vazada numa reapreciação de figuras históricas controversas. O caudilho Juan Manuel de Rosas serviu como medida de argentinidade dessa perspectiva militante. A derrota de Rosas em Caseros (1852) fora a senha para a paulatina destruição do mundo criollo, com a ocupação dos pampas pela agricultura de exportação, pela construção das ferrovias e pelas políticas incentivadoras da imigração. Esse esquema de contrastes gritantes vai adquirindo feições que se resumem, de um lado, numa condenação dos gringos, do elemento estrangeiro, da cultura européia e, de outro, numa exaltação do gaúcho, de uma ignorância telúrica tida como depositária dos atavios autênticos do nativismo.

O jovem Borges não desdenhou o combate ideológico travado inclusive na arena conceitual das classificações, conferindo voltagem e personalidade à noção arcaica de criollidad em lugar de "argentinidade", e buscando situar, designar e qualificar os suportes materiais e simbólicos desse modo de ser na cultura popular, na tradição literária, nos autores que lhe pareciam encarnar e sustentar o vigor dessa originalidade civilizacional. Em lugar da apreensão passadista, que pudesse se contentar em repor as perdas de substância assinaladas, Borges intentou garantir outros fundamentos à renovação dos mitos criollos, adaptando-os, na medida do factível, às circunstâncias cambiantes das lutas ideológicas naquela conjuntura. Logo, a representação literária de traços típicos do que ele designou como "lírica criolla" 
é bastante similar às idéias sustentadas por Lugones, em especial a tendência a explicar a lírica gauchesca em função de peculiaridades da geografia dos pampas e do estilo inconfundível de vida.

Em vez de salientar a herança racial e cultural da criollidad, como faziam alguns luminares da geração precedente - Gálvez, Rojas, Lugones - o jovem Borges equacionou o dilema em termos de engajamento político, a começar pela audácia de revirar de ponta cabeça o antigo debate entre civilização e barbárie. Recusou as arengas liberais, sobretudo a postura modernizante sustentada por Sarmiento, e recuperou uma civilização criolla que o estadista indigitara como atraso e carência de progresso. A linguagem dos primeiros poemas encampa a linha nacionalista expressa em Inquisiciones, podendo-se, assim, enxergar Borges como exegeta de um grupo social específico, a gente decente e "bem nascida", os integrantes do seu círculo íntimo de convívio, mostra representativa da elite cultural argentina.

Fervorde Buenos Aires reúne 45 composições já bastante demarcadas em relação ao credo ultraísta, nas quais predominam o tom intimista, as lembranças da infância, da família, da casa dos pais, do bairro onde cresceu e de outras vizinhanças na cidade de Buenos Aires, da história e da civilização argentinas ${ }^{31}$. $O$ assunto substantivo da coletânea, que perpassa todos os eixos temáticos abordados, é a evocação nostálgica da classe de origem por meio das experiências, lembranças e valores de seu círculo de sociabilidade.

Um terço dos poemas tematiza a Buenos Aires das vizinhanças de classe média e alta nos bairros da região nucleada em torno de Palermo, alheando-se do rebuliço do porto e dos logradouros agitados do centro comercial. Borges prefere mirar as ruas tranqüilas dos bairros afastados, daqueles arrabaldes onde o campo ainda resiste ao avanço da cidade, como bem o demonstram inúmeras incursões líricas ao longo do livro. A opção pelo sítio urbano contemplado pelo estro lírico se faz acompanhar pela compaixão endereçada aos pares criollos, em detrimento dos imigrantes, em especial os italianos. Essa predileção por uma Buenos Aires do descampado, dos quarteirões retilíneos, de casas baixas, éo reverso do rechaço da região portuária, da agitação mercantil dos negócios, dos anúncios luminosos, dos prédios altos. O poeta estreante enxergou Buenos Aires da perspectiva de sua casa e do bairro de Palermo em que estava situada, região apartada do centro, entrecortada de praças vazias e povoada de casas térreas, providas dos elementos arquitetônicos e decorativos característicos da vivência criolla vestíbulos, balaustradas, balcões, beirais de telhado, pátios e cisternas.

Nesses ambientes, a ritmação do cotidiano era medida pelas pausas impostas pelo estilo de vida, como os momentos de fruição do mate, por exemplo, e não pelos relógios modernos. As referências esparsas aos imigrantes embutem lamúrias de um mundo que está se
[31] Ficaram de fora cerca de duas dezenas de poemas de inequívoca entonação política, compostos entre 1919 e 1922, alusivos aos horrores da Primeira Guerra Mundial e às transformações acarretadas pela revolução socialista de 1917 - «Trinchera», «Rusia», "Gesta maximalista» —, os quais não correspondiam mais às inclinações doutrinárias do jovem Borges. 
[32] Ver Beatriz Sarlo.Borges, un escritoren las orillas. Bueno Aires: Seix Barral, 2003. esboroando, dando alento às queixas pela perda de traços nativos. $\mathrm{O}$ jovem Borges assumiu uma postura lírica defensiva, resistindo a tratar literariamente dos elementos modernos e cosmopolitas de Buenos Aires, então em ritmo frenético de mudança.

Borges é um andarilho antenado, munido de lentes possantes para registrar o próprio universo social. Sua perambulação descarta os espaços em que transitam os trabalhadores imigrantes, na busca quase obcecada pelos poentes fantasmagóricos tão bem exaltados no livro. Tais preferências e idiossincrasias foram anotadas pelos primeiros críticos e resenhistas da obra, e mais tarde reprocessadas como matéria-prima em análises centradas na dimensão ideológica das obras de Borges naquele período.

Os poemas se repartem em torno de cinco eixos temáticos - Buenos Aires, reminiscências familiares, "argentinidade", metafísica e vivência amorosa -, embora alguns deles possam ser encaixados em diversas rubricas. Quero interpretá-los aqui em termos de uma apreensão muitíssimo apurada de suas experiências de classe, como expressão dos reclamos daquela parcela derrotada da elite de onde provinha e com a qual se identifica. Ele estava imbuído do sentido doutrinário de seu proselitismo literário e da relevância estratégica de seu experimento, por assim dizer, de delegação poética. Se a originalidade da poesia borgeana, como sugere Beatriz Sarlo32, reside na conjunção de vetores potencialmente contraditórios - a postura do resgate criollista temperada pelas inovações da linguagem de vanguarda -, frise-se o quanto esse recado fervoroso logrou vocalizar os queixumes classistas. A retomada dos mesmos temas equacionados em chave poética nos termos discursivos dos ensaios reforça a incidência contundente do vetor ideológico por detrás de ambas modalidades de expressão.

Contraposta ao alvorecer dos operários para outra jornada de trabalho, a tarde constitui o momento ideal para as andanças do poeta, como que realçando e infundindo cores nostálgicas aos procedimentos da memória classista. Os poemas consagrados ao tratamento elegíaco de Buenos Aires são, em maioria, reconhecíveis pelo nome dos logradouros nos títulos. Tais sítios configuram um cinturão em torno de Palermo, o bairro mítico em cujo território foi erguida a casa dos pais, o espaço de socialização afetiva, modelo no qual se podem rastrear os componentes mágicos desse cenário de gênese de uma sensibilidade criolla.

"O Jardim Botânico", por exemplo, se localiza na divisa de Palermo, bem próximo da calle Serrano, demarcando o território urbano em que transitam nosotros, aqui evocados por meio de sensualidades ajustadas à posição e à idade dos "viventes": a conjugal, tingida pelo travo incestuoso; a libidinosa, travada por interditos. "A praça San Martín", dedicado a Macedonio Fernández, "espectador apaixonado de Buenos 
Aires", o modelo masculino do autor, relança o poeta numa apreensão, em câmera lenta, dos espaços privilegiados dessa interação entreiguais. "A Recoleta", nome do cemitério encravado na região elegante da alta burguesia, insinua certa impregnação daquela criollidad ameaçada de extinção, incitando-o a fazer um paralelo entre a morte dos entes próximos e a tomada de consciência de sua sina ${ }^{33}$. A imagem do cemitério provoca uma reversão de expectativas, o hálito estranho de uma ressurreição das esperanças mundanas por meio do ofício poético.

"Vila Urquiza" enaltece o bairro da periferia, o arrabalde que está deixando de ser rural. "Caminhada" aprofunda essa errância do bardo, agora exposto aos vestígios tangíveis de um mundo social em desagregação: o perfume dos vapores do mate, os cheiros do mato, as hortas recobertas pelo asfalto, a especulação imobiliária. O fecho torna o poeta espectador vicário de um mundo fantasma, dessorado, esgarçado, habitado por vultos reminiscentes de uma sociabilidade pretérita. "Rua desconhecida" chafurda nos devaneios decepcionados do autor, como que prensado entre as constrições familiares, que o empurram para o refúgio do trabalho intelectual, e as servidões temporais com escassas rotas de escape à desdita social34. O vislumbre do candelabro judaico metaforiza o contraponto entre as gerações familiares, cujo convívio caloroso não logrou reverter o destino social dos mais jovens, premidos pelos impasses derivados da cegueira paterna35.Vidas cúmplices, interdependentes, os moços atingidos em cheio pelas vicissitudes dos adultos.

As evocações familiares ancoram outro conjunto de composições e esclarecem as motivações mais doídas do poeta, como se fora o ventríloquo de uma classe acossada. "Sala vazia" exibe flagrantes de um cômodo desgastado, no qual os restos do passado de ostentação permitem recompor os laços de família.

$$
\begin{aligned}
& \text { Los muebles de caoba perpetúan } \\
& \text { entre la indecisión del brocado } \\
& \text { su tertulia de siempre. ("Sala vazia") }
\end{aligned}
$$

Os versos do terceto inicial remontam uma conversa entre fantasmas, em que os dialogantes são os móveis com tecido puído.
[33] «Lo anterior: escuchado, leído, meditado lo realicé en la Recoleta, junto al proprio lugar donde han de enterrarme." ("A Recoleta»)

\footnotetext{
[34] «Intimo y entrañable era el milagro de la calle clara y solo después entendíque aquel lugar era extraño, que es toda casa un candelabro donde arden con aislada llama las vidas que todo inmediato paso nuestro camina sobre Gólgotas ajenos.» («Rua desconhecida»)

[35] Em 1923, o pai já estava cego, aos 44 anos, e Jorge Luis já começava a enxergar mal.
}

\author{
Los daguerreotipos \\ mientem su falsa cercania \\ de vejez enclaustrada en un espejo \\ $y$ ante nuestro examen se escurren \\ comofechas inútiles \\ de aniversarios borrosos.
}


A estrofe seguinte focaliza os retratos emoldurados, pendurados na parede, imagem de grande impacto, cujos personagens, remoçados nas fotos, recobram suas ligações numa verossimilhança desbotada. Estampas de gente que era moça naquele tempo caduco, de sala cheia.
Con ademán desdibujado
su casi-voz angustiosa
corre detrás de nuestras almas
con más de medio siglo de atraso
yapenas si estaráahora
en las mañanas de nuestra infancia.

A cena subseqüente rememora o vozerio desses personagens, na força da idade, jovens adultos que cuidavam do poeta criança.

La actualidad constante
convincente y sanguínea
aplaude en el trajin de la calle
su plenitud irrecusable
de apoteosis presente
mientras la luz a puñetazos
abre un boquete en los cristales
y humilla las seniles butacas
y arrincona y ahorca
la voz lacia
de los antepasados

A cena toda se anima de repente, o barulho da rua ressoa no interior do cômodo entregue às baratas, e o fulgor da vida presente cintila nos cristais e revela o mau estado das poltronas avariadas. O poema se fecha com menção à voz cansada dos antepassados, afeitos à abastança, numa sala com móveis de peroba, lustres de cristal e poltronas de brocado. Eis o poema-chave do livro, cujos versos condensam o substrato histórico de uma falência coletiva, ora reciclada como matéria literária, objeto de memória, apagamento sensível, energia filtrada por um dialeto expressivo destinado à fruição de uma minoria de outros decaídos.

"Final de ano" invoca um momento intenso da sociabilidade

[36] «es el azoramiento ante el milagro de que a despecho de alternativas tan inifinitas

pueda persistir algo en nosotros inmóvil» ("Final de ano»)

[37] «Lindo es vivir en la amistad oscura de un zaguán, de un alero y de un aljibe.» ("Um pátio»). familiar, no qual se comemora a passagem do tempo, a despeito do sentimento inarredável de clausura do poeta em sua condição social36. "Um pátio" louva o espaço mágico da casa, na confluência do mais íntimo com o mais externo - o vestíbulo, os beirais do telhado, o poço, a terra e o céu -, síntese de um ideal apaziguado de convívio criollo, exaltando o universo familiar como núcleo da vida verdadeira37. No poema "Vizinhanças", a evocação do pátio dilata as 
esferas de circulação, num lugar geométrico entre o ambiente externo das ruas de arrabalde e as alcovas com espelho e móveis de peroba ${ }^{38}$. "A volta" é outra variante dessa viagem poética pelas paragens da infância, pelos sítios fronteiriços à casa paterna, "província de minha alma".

As duas composições intituladas "Inscrição sepulcral", dedicadas aos bisavôs materno (Isidoro Suárez, 1799-1846) e paterno (Francisco Borges, 1832-1874), restituem a linhagem familiar na legenda de uma elite nativista, pela exaltação de heróis patriotas. $\mathrm{O}$ bisavô materno é o elo com a independência argentina, por ter participado da batalha de Junín contra o exército espanhol e, até mais importante, da perspectiva do jovem Borges revisionista, responsável pelo parentesco torto da família com o caudilho Rosas, parente afastado da bisavó uruguaia. O bisavô paterno, ferido de morte em batalha, lutou na Guerra do Paraguai e atuou no comando sob as ordens de Mitre, chefe da facção derrotada nas guerras de unificação. Os versos encomiásticos inscrevem o nome da família nos embates decisivos da história nacional, conferem legitimidade à vocação nativista do poeta-ideólogo e propagam os fumos de pretensão social do clã Borges. Atitude poética idêntica à de Lugones ao reivindicar o título de bardo nacional, vinculando tal mandato aos feitos guerreiros dos antepassados.

Os poemas "O truco" e "Rosas" reconsideram a figura lume da história argentina, o caudilho onipotente Juan Manuel de Rosas, o ás de espadas, na visada favorável do jovem Borges entronizado como verdadeiro pai da pátria. O tirano libertador teria sido a liderança providencial, o rosto vigoroso e apaixonado desse "outro país" que não se consegue enxergar na capital, o homem emblemático da Argentina profunda, imersa na "realidade primordial do gozo e sofrimento carnais", de uma história cíclica, destino prefigurado.

\author{
En el ámbito desamorado \\ de la sala taciturnamente rendida \\ cuyo relojaustero derrama \\ un tiempo ya sin aventura ni asombro \\ sobre la lastimosa blancura \\ que amortaja la pasión roja de la caoba, \\ alguien en queja de cariño \\ pronunció el nombre familiarmente horrendo. ("Rosas")
}

O poema "Rosas" se inicia num cômodo similar àquele evocado em "Sala vazia", com mobília de peroba e relógio de parede, de molde a justificar a invocação do "nome familiarmente horrendo" em virtude dos já mencionados longínquos laços de parentesco.

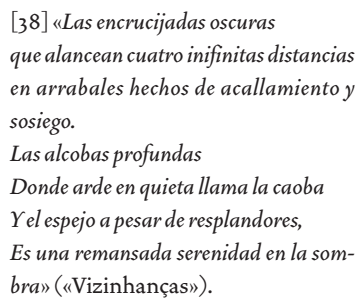


[39] «La sombra es apacible como una lejanía:

bien recuerdan las calles

que fueran campo un día." ("A noite de São João»).

[40] «Anuncios luminosos tironeando el cansancio.

...

Colores impetuosos

Escalan las atónitas fachadas.

...

y es tu recuerdo como un ascua viva que nunca suelto

aunque me quemam las manos".

\section{Famosamente infame}

ese nombre fuédesolación en las calles,

idolátrico amor entre el gauchaje

y horrorde puñaladas en la historia.

A tensão narrativa se estriba numa conjunção contraditória "familiarmente horrendo" e "fervorosamente infame" —, no intuito, decerto, de incensar nas lutas pela afirmação nacional o personagem ímpar como encarnação vibrante das expectativas antiliberais da geração emergente de letrados. O jovem Borges absolve o déspota dos crimes e desmandos, por conta da necessidade premente de convertê-lo em reserva espiritual e núcleo de resistência ao ímpeto das reformas liberais que estão mudando as feições do país.

No ensaio-libelo de Inquisiciones, "Queixa de todo criollo", Borges explicita sua postura revisionista da história argentina.A derrota infligida a Rosas teria acarretado a destruição do mundo criollo, arrasado pela valorização das terras, o que impulsionou a agricultura de exportação em detrimento da pecuária extensiva, levando na enxurrada os personagens gaúchos que viviam à sombra da economia autárquica.A tragédia criolla teria então se consumado pela ocupação produtiva dos pampas, pela dissolução do gauchismo, por uma depreciação cultural avassaladora dos afazeres e costumes dos criollos.

"Música pátria" recupera alguns elementos típicos da criollidad,em especial o romanceiro festivo que se exprime pela cantilena de motivos autóctones, costurados pela batida melódica, que se resolve num bordão nativo marcante. O ressoar dessa música é tanto mais tocante quando o poeta se confunde com a figura do caminhante, paralisado de emoção ao reconhecer a música da terra: "siente como si le palparan el corazón con la mano". Esse poema também se presta a uma leitura hispanicista, de louvação aos feitos espanhóis, desde a expulsão dos árabes, passando pelas conquistas nas Índias, até se instalarem nos pampas, desta feita a música vibrando pela voz da guitarra criolla, em meio à matança dos índios. "A noite de São João" reitera a lamúria por aquele mundo que está desmoronando, as guitarras e o fogaréu nas ruas, uma cidade em convulsão, onde "as ruas foram campo um dia"39.

A lembrança da amada reponta no poema "Cidade", no qual o jovem Borges rechaça os emblemas gritantes da modernidade, quase um refrão a percorrer o livro inteiro, ao contrapor a afetividade do aconchego familiar à estridência do tumulto urbano ${ }^{40}$. Em "Ausência", o lamento sofrido pela perda amorosa recobre a paisagem, a passagem do tempo, as palavras, sinais evocativos do ente querido: "Tu ausencia ciñe el alma/como cuerda que abarca una garganta".

O poema "Sábados", dedicado à noiva Concepción Guerrero, rememora os encontros do casal desfeito, talvez na sala da família 
Lange, onde se conheceram e onde costumavam se ver, embalados pela música no piano.

\author{
Siempre la multitud de tu hermosura \\ en claro esparcimiento sobre mi alma. \\ ... \\ El corazón refleja \\ Tus labios que una noche serán besos \\ $\cdots$ \\ En ti estála delicia \\ Como está la crueldade en las espadas. \\ Sobrevive a la tarde \\ Lablancura gloriosa de tu carne. \\ Tú \\ Que ayer solo eras toda la hermosura \\ Eres también todo el amor, ahora.
}

O poema crava certa veemência amorosa que se faz perceptível na oscilação entre imagens esquivas e físicas da amada: a beleza, a voz, os lábios, a carne. Os poemas "Flor de âmbar" e "Troféu" modulam a queixa suscitada pelo amor rompido, o poeta lembrando das andanças do casal enamorado pela cidade.

"Despedida" inclui os versos de amor que encerram o livro, numa alusão inequívoca à segunda viagem familiar à Europa, a qual selou o destino social do jovem Borges, obrigando-o a romper o noivado.

\title{
Entre mi amory yo han de levantarse \\ trescientas noches como trescientas paredes \\ y el mar será un milenio entre nosotros.
}

Os versos finais como que prenunciam a resignação do poeta diante de sua desdita afetiva, o reverso da unção como porta-voz genuíno da nova geração literária. O livro de estréia prenunciava os rumos do mandato de vida e trabalho que lhe fora designado e em nome do qual o poeta-ensaísta abdicava da paixão. 